\title{
Combining Ability and Heterosis in Sugarcane for Early Selection Traits
}

\author{
Y. Bharathi ${ }^{1 *}$, Firdoz Shahana ${ }^{2}$, T. Prabhakar Reddy ${ }^{2}$ and M. Vijaykumar ${ }^{3}$
}

${ }^{1}$ Department of Seed Science and Technology, Seed Research and Technology Centre, Professor Jayashankar Telangana State Agricultural University, Rajendranagar, Hyderabad-500030, India

${ }^{2}$ Regional Sugarcane and Rice Research Station, Rudrur, Nizamabad (Dist), India ${ }^{3}$ Agriculture Research Station, Basanthapur, Telangana state, India

*Corresponding author

\section{A B S T R A C T}

\section{Keywords}

Sugarcane, Inbreds, Combining ability, Heterosis, Millable canes, Cane thickness, HR brix

Article Info

Accepted:

20 June 2020

Available Online:

10 July 2020
The present study on sugarcane cross derivatives involving 'Co' clones, it was found that specific combining ability was more important than general combining ability for number of millable canes (NMC), cane thickness and HR brix. The inbred 83 R 23 was the best general combiner for NMC, cane thickness and HR brix. Contribution of line $\times$ tester interaction to the total variance for NMC was the highest in testers $(72.58 \%)$ followed by that of lines (32.98\%). Among the testers, Co 775 was found to be a good combiner for NMC and Co 89003 for HR brix. Three crosses, viz., 83 R 23x Co 89003, 83 R 23x Co 775, and Co 98014x Co 89003 were the best specific combiners for NMC. Among the 15 crosses, the three crosses Co 7219x Co 775, Co C 671x Co 89003 and Co 98013x Co 89003 recorded significant and desirable heterosis for HR brix.

\section{Introduction}

Sugarcane is grown as a commercial crop in both tropical and subtropical regions of India in 47.74 lakh ha with a productivity of 74.4 t/ha during 2017-18 (https://sugarcane. dac.gov.in/ pdf/ Statistics APY.pdf). The Sugarcane improvement programme involves hybridization and selection as a continuous process to generate variability. The study of progenies resulting from hybridization in the cropis of great importance to identify desirable parents and to measure the effectiveness of the selection among the progenies.

Choice of parents can be determined by factors such as breeding goals, available 
materials, flowering time and breeding behaviour of parents in specific cross combinations and by the amount of information available on any parent or cross combinations. The polyploidy nature and high levels of heterozygosity have made sugarcane breeding an unpredictable breeding programme and it makes difficult to choose the parents. However, Hogarth (1987) opined that although there is some imprecision, genetic analysis of traits is possible in sugarcane despite epistasis and polyploidy. Killick (1977) also observed that evaluation of combining abilities and genetic parameters are not greatly affected by ploidy level. Chen et al., (1986) stressed the importance of evaluating the parents before attempting crosses while studying the inheritance of quantitative characters in sugarcane. Cassalett et al., (1996) concluded that the genotypes generated through inbreeding can be reliable donors with predictable improved performance. Line $\mathrm{x}$ tester analysis is one of the best methods used to select the parental material for hybridization from the pool of genotypes and to identify their genetic worth. The mating is effected in all possible combinations keeping the sex of parent constant.

The progenies resulting from line $\mathrm{x}$ tester mating, along with or without the parents, can be tested using suitable field design. Line $x$ tester analysis has been applied to evaluate sugarcane with regard to quantitative characters (Punia 1986; Bakshi Ram and Hemaprabha 2000; Lourdusamy and Anbuselvam 2009; Alarmelu et al., 2010), red rot resistance (Bakshi Ram et al., 2005) andagronomic and biochemical characters (Tyagi and Lal 2005). The studies using sugarcane inbreds as parents are lacking although several studies are available on combining ability and heterosis of sugarcane that inbreds transmit the characters of interest to their progeny with certainty and the breeding value of inbreds as parents can be measured precisely. Hence, the present study was under taken to estimate the variance components, general and specific combining ability effects and heterosis in the progenies produced by line $\mathrm{x}$ tester crosses involving selected sugarcane inbreds and 'Co' clones for early stage selection traits, viz. number of millable canes (NMC), cane thickness and HR brix.

\section{Materials and Methods}

The material for the study comprised six female parents (lines), namely the inbreds Co 98013, Co C 671, Co 7219, Co 98014, ISH 100 and $83 \mathrm{R} 23$ and three male parents (testers), namely Co $775\left(\mathrm{~T}_{1}\right)$, Co $1148\left(\mathrm{~T}_{2}\right)$ and Co $89003\left(\mathrm{~T}_{3}\right)$. The female parents selected are advanced varieties of the subtropical region and males selected are genotypes predominantly used as parents in the national hybridization programme. The selection of these parents was based on cane yield, sucrose content, resistance to red rot and flowering traits. The inbreds were pollinated with pollen from selected males to produce crosses. Line $\mathrm{x}$ tester matings made during the 2016crossing season using six lines and three testers resulted in $18 \mathrm{~F}_{1}$ crosses. The seeds of each cross were packed separately in plastic bags and stored at $-20^{\circ} \mathrm{C}$. During February 2016, the seeds were germinated in trays which were transferred from the glasshouse after two weeks and kept in open environment for hardening. After hardening for three weeks, the seedlings were transplanted in the main field in randomized complete block design with two replications during mid-May2016. From each cross and parent, 40 seedlings/ settlings were transplanted in each replication. Data on NMC, cane thickness (cm) and HR brix (\%) were taken at $11^{\text {th }}$ month after transplanting. Analysis of variance was performed to calculate $\mathrm{F}$ values among the genotypes including crosses and parents. Line $\mathrm{x}$ tester analysis was carried out following the 
methodology described by Singh and Chaudhary (1985).

\section{Results and Discussion}

\section{Analysis of variance}

Analysis of variance for the characters studied indicated genetic differences among genotypes. The significant variation due to parents and line $\mathrm{x}$ tester interaction $(\mathrm{L} \times \mathrm{T})$ indicated heterotic response in the progenies of the crosses (Table1). The estimates of variance due to specific combining ability (sca) and general combining ability (gca) and their ratio revealed that the sca was higher than the gca for all the characters studied. This indicated the predominance of nonadditive gene action controlling these characters. Similar trend was observed for several yield and quality parameters in earlier studies (Alarmelu et al., 2010; Lourdusamy and Anbuselvam 2005).

However, Wu et al., (1980) reported predominance of gca effect for NMC, cane diameter, cane length and sucrose and Bressiani et al., (2002) for brix (\%), cane yield, brix yield, stalk number, reaction to rust and pithiness. Additive and dominance gene action was reported by Hongkai (2009) and Bakshi Ram et al., (2005) respectively for stalk number and red rot resistance index. The gca effect which is attributed to additive gene action and additive $\mathrm{x}$ additive gene interaction is fixable. The non-additive type of gene action obtained in the present study could be exploited in hybrids since most of sugarcane varieties are $F_{1}$ hybrids between different selected parents. The difference in combining ability effects for the same traits, particularly observed among inbreds and between inbreds and other genotypes, may be attributed to difference in genetic constitution of the genotypes and their ability to transmit the same to their progenies. Lines contributed higher towards cane thickness (69.43\%) followed by line $\mathrm{x}$ tester interaction. The contributions of lines and lines $\mathrm{x}$ testers to the total variance for HR brix were 49.85 and $48.20 \%$, respectively. These results were in partial agreement with those of Rai $e t$ al., (1991) whore ported higher contribution of lines for NMC, cane diameter, cane length, single cane weight and stool weight; Tyagi and Lal (2005) who reported predominant effect of lines for cane thickness, testers for brix and line $\mathrm{x}$ tester interaction effect for NMC; Punia (1986) reported maximum contribution of lines to the total variance of cane diameter and line $\mathrm{x}$ tester interaction for NMC. Contribution of lines to the total variance, which is always high irrespective of the usage of inbreds in the present study and other genotypes in earlier studies, indicated that female parents and their interaction with male parents decide the variation among their progenies for these traits.

\section{Evaluation of parents}

General combining ability of parents for different characters is given in Table 3. The female parent $83 \mathrm{R} 23$ was identified as a good general combiner for NMC, an important component trait of cane yield. All the genotypes having higher per se performance for NMC are not good general combiners. In this case, two genotypes, viz. Co 98014 and Co 89003 were good with respect to per se performance. However, gca effect were negative for Co 98014 and Co 89003. 
Table.1 ANOVA for Line x Tester design involving inbreds and Co clones for agronomic characters

\begin{tabular}{|l|c|c|c|c|}
\hline Source & df & NMC & Cane thickness & HR brix \\
\hline Replications & 1 & 0.116 & 0.004 & 0.216 \\
\hline Genotypes & 24 & $4.341^{*}$ & $0.056^{* *}$ & $2.416^{* *}$ \\
\hline Lines & 5 & 4.986 & 0.094 & 3.841 \\
\hline Testers & 2 & 0.304 & 0.02 & 2.034 \\
\hline Lines x testers & 10 & $5.819 * *$ & $0.04 *$ & $2.48 * *$ \\
\hline Error & 16 & 0.501 & 0.008 & 0.245 \\
\hline $\mathbf{\Sigma 2 s c a}$ & & $3.21 *^{*} *$ & $0.009 *$ & 0.922 \\
\hline $\mathbf{\Sigma 2 g c a}$ & & 0.319 & 0.007 & 0.382 \\
\hline $\mathbf{\Sigma 2 s c a} / \mathbf{\Sigma 2 g c a}$ & & 12.08 & 2.250 & 2.941 \\
\hline
\end{tabular}

$* \mathrm{P}<0.05 ; * * \mathrm{P}<0.01$

Table.2 Proportion of contribution of lines (inbreds) and testers (Co clones) and their interaction to the total variance for agronomic characters

\begin{tabular}{|l|c|c|c|}
\hline Source of variation & NMC & $\begin{array}{c}\text { Cane } \\
\text { thickness }\end{array}$ & HR brix \\
\hline Lines & 32.98 & 69.43 & 49.85 \\
\hline Testers & 0.76 & 0.04 & 13.24 \\
\hline Lines and testers & 72.58 & 38.56 & 48.20 \\
\hline
\end{tabular}

Table.3 General combining ability and per se performance of inbreds and Co clones

\begin{tabular}{|c|c|c|c|c|c|c|}
\hline \multicolumn{4}{|c|}{ General combining ability } & \multicolumn{3}{|c|}{ Per se performance } \\
\hline Parents & NMC & $\begin{array}{l}\text { Cane } \\
\text { thickness }\end{array}$ & HR brix & NMC & $\begin{array}{l}\text { Cane } \\
\text { thickness }\end{array}$ & HR brix \\
\hline \multicolumn{7}{|c|}{ Lines } \\
\hline Co 98013 & 0.110 & $-0.099 *$ & $0.956 * *$ & 3.5 & 2.16 & 18.4 \\
\hline Co C 671 & 0.362 & $0.213 * *$ & $0.843 * *$ & 3.2 & 2.25 & 17.1 \\
\hline Co 7219 & $-0.943 *$ & $-0.098 *$ & -0.012 & 4.5 & 2.30 & 15.9 \\
\hline Co 98014 & $-0.827 *$ & 0.070 & $-0.786 * *$ & 4.5 & 2.35 & 18.6 \\
\hline ISH 100 & $1.120 * *$ & -0.082 & $-0.807 * *$ & 5.0 & 2.40 & 18.9 \\
\hline 83 R 23 & $1.324 * *$ & $0.421 * *$ & $1.025 * *$ & 5.5 & 2.56 & 19.2 \\
\hline \multicolumn{7}{|c|}{ Testers } \\
\hline Co 775 & 0.186 & 0.004 & 0.327 & 4.0 & 2.15 & 18.7 \\
\hline Co 1148 & -0.099 & 0.006 & -0.523 & 3.0 & 2.35 & 19.2 \\
\hline Co 89003 & -0.079 & 0.004 & $0.427 *$ & 5.0 & 2.25 & 19.0 \\
\hline
\end{tabular}


Table.4 Per se performance and the effect of specific combining ability of the crosses involving inbreds of sugarcane

\begin{tabular}{|l|c|c|c|c|c|c|}
\hline Crosses & \multicolumn{2}{|c|}{ Specific combining ability effects } & \multicolumn{3}{c|}{ Per se performance } \\
\hline Co 98013x Co 775 & NMC & Cane thickness & HR brix & NMC & Cane thickness & HR brix \\
\hline Co 98013x Co 1148 & 0.725 & -0.079 & $-0.120^{* *}$ & 6.16 & 2.07 & 17.25 \\
\hline Co 98013x Co 89003 & -0.840 & -0.132 & 0.510 & 5.48 & 2.09 & 18.73 \\
\hline Co C 671x Co 775 & 0.703 & 0.028 & $-0.699^{*}$ & 6.55 & 2.27 & 17.35 \\
\hline Co C 671x Co 1148 & $-1.137 *$ & 0.075 & -0.086 & 4.73 & 2.39 & 17.99 \\
\hline Co C 671x Co 89003 & 0.523 & -0.092 & $0.817^{* *}$ & 6.28 & 2.28 & 19.60 \\
\hline Co 7219x Co 775 & -0.920 & -0.027 & $1.720^{* *}$ & 3.94 & 2.12 & 19.53 \\
\hline Co 7219x Co 1148 & 0.310 & 0.042 & $-1.190^{* *}$ & 4.55 & 2.05 & 16.58 \\
\hline Co 7219x Co 89003 & 0.644 & -0.028 & $-0.730^{*}$ & 5.10 & 2.14 & 17.12 \\
\hline Co 98014x Co 775 & $-1.803^{* *}$ & 0.132 & 0.026 & 3.32 & 2.23 & 17.21 \\
\hline Co 98014x Co 1148 & -0.513 & 0.005 & 0.263 & 4.16 & 2.25 & 16.75 \\
\hline Co 98014x Co 89003 & $2.319^{* *}$ & -0.113 & -0.252 & 7.03 & 2.19 & 17.01 \\
\hline ISH 100x Co 775 & $1.530^{* *}$ & -0.042 & 0.026 & 8.26 & 2.13 & 17.18 \\
\hline ISH 100x Co 1148 & $1.180^{*}$ & 0.024 & 0.417 & 7.53 & 2.12 & 16.87 \\
\hline ISH 100x Co 89003 & $-2.63^{* *}$ & 0.028 & -0.413 & 4.13 & 2.17 & 16.82 \\
\hline 83 R 23x Co 775 & $2.518^{* *}$ & 0.035 & $1.954^{* *}$ & 9.54 & 2.58 & 19.45 \\
\hline 83 R 23x Co 1148 & $1.842^{* *}$ & 0.182 & $1.527^{* *}$ & 9.8 & 2.67 & 19.65 \\
\hline 83 R 23x Co 89003 & $2.623^{* *}$ & 0.235 & $1.996^{* *}$ & 9.1 & 2.49 & 19.84 \\
\hline
\end{tabular}

$* \mathrm{P}<0.05 ; * * \mathrm{P}<0.01$

Table.5 Percentage of relative heterosis and heterobeltiosis of crosses involving inbreds of sugarcane for agronomic characters

\begin{tabular}{|c|c|c|c|c|c|c|}
\hline \multirow[t]{2}{*}{ Crosses } & \multicolumn{2}{|c|}{ Number of millable canes } & \multicolumn{2}{|c|}{ Cane thickness } & \multicolumn{2}{|c|}{ HR brix } \\
\hline & $\begin{array}{l}\text { Relative } \\
\text { heterosis }\end{array}$ & $\begin{array}{c}\text { Hetero } \\
\text { beltiosis }\end{array}$ & $\begin{array}{l}\text { Relative } \\
\text { heterosis }\end{array}$ & $\begin{array}{c}\text { Heterobelti } \\
\text { osis }\end{array}$ & $\begin{array}{l}\text { Relative } \\
\text { heterosis }\end{array}$ & $\begin{array}{c}\text { Hetero } \\
\text { beltiosis }\end{array}$ \\
\hline Co 98013x Co 775 & $61.75 * *$ & $44.46 * *$ & -4.06 & -7.82 & -1.37 & $-3.63^{*}$ \\
\hline Co 98013x Co 1148 & $65.84 * *$ & $65.74 * *$ & $-9.20 * *$ & -10.10 & 0.87 & -0.16 \\
\hline Co 98013x Co 89003 & 11.22 & -7.58 & 4.03 & 2.14 & $5.14 * *$ & $3.54 *$ \\
\hline Co C 671x Co 775 & $81.07 * *$ & $50.54 * *$ & 3.00 & -5.25 & $4.03 *$ & 1.17 \\
\hline Co C 671x Co 1148 & $49.77 * *$ & $39.00 *$ & 1.82 & -3.44 & 2.07 & -2.15 \\
\hline Co C 671x Co 89003 & $50.94 * *$ & 17.18 & -1.56 & $-8.09 *$ & $10.48 * *$ & $6.37 * *$ \\
\hline Co 7219x Co 775 & -4.31 & -9.00 & -3.06 & -7.70 & $17.16^{* *}$ & $9.23 * *$ \\
\hline Co 7219x Co 1148 & $29.00 *$ & 22.75 & -4.85 & -5.90 & -2.07 & $-9.42 * *$ \\
\hline Co 7219x Co 89003 & 10.58 & -3.44 & -5.05 & -7.70 & $4.56^{*}$ & -3.22 \\
\hline Co 98014x Co 775 & -20.34 & -20.22 & $8.21 *$ & 3.98 & $-4.52 * *$ & $-6.59 * *$ \\
\hline Co 98014x Co 1148 & 12.45 & 1.01 & 0.00 & 0.00 & $-7.91 * *$ & $-9.12 * *$ \\
\hline Co 98014x Co 89003 & $40.10 * *$ & $28.29 *$ & -2.18 & -4.18 & $-6.18 * *$ & $-7.71 * *$ \\
\hline ISH 100x Co 775 & $76.95 * *$ & $68.00 * *$ & -3.06 & $-7.00 *$ & $-5.60 * *$ & -8.14 \\
\hline ISH 100x Co 1148 & $84.28 * *$ & $57.20 * *$ & -5.15 & -5.80 & $-8.40 * *$ & $-9.30 * *$ \\
\hline ISH 100x Co 89003 & -16.14 & $-19.91 * *$ & -2.98 & -5.10 & $-7.13 * *$ & $-9.20 * *$ \\
\hline 83 R 23x Co 775 & $88.12 * *$ & $72.45 * *$ & $9.12 *$ & 3.12 & $18.25 * *$ & $-9.27 * *$ \\
\hline 83 R 23x Co 1148 & $85.34 * *$ & $74.13 * *$ & $8.45^{*}$ & 4.29 & $16.47 * *$ & $-8.45 * *$ \\
\hline 83 R 23x Co 89003 & $74.36 * *$ & $68.39 * *$ & $9.30 *$ & 3.87 & $18.46^{* *}$ & $-4.23 * *$ \\
\hline SE & 0.517 & 0.602 & 0.068 & 0.079 & 0.255 & 0.280 \\
\hline CD95\% & 1.052 & 1.231 & 0.146 & 0.191 & 0.532 & 0.771 \\
\hline CD 99\% & 1.399 & 1.717 & 0.181 & 0.241 & 0.708 & 1.047 \\
\hline
\end{tabular}

$* \mathrm{P}<0.05 ; * * \mathrm{P}<0.01$ 
In case of HR brix, 83 R 23, Co 98013 and Co 89003 were good general combiners. Among them, 83 R 23 and Co 89003 were better performing (perse) parents. Similarly, Bakshi Ram et al., (2005) could not establish any correlation between gca and per se performance of parents for red rot disease index. The behavior of the parents with similar per se performance and different gca effects indicated non-additive gene action controlling the trait in question. However, 83 R 23 and ISH 100 recorded higher per se performance for cane thickness which was also found as a good combiner for this trait. Similarly a close relationship between per se performance and combining ability indicating predominance of additive $\mathrm{x}$ additive gene action was reported earlier (Alarmelu et al., 2010; Anna Durai and Hema Prabha, 2016). Among the inbreds, $83 \mathrm{R} 23$ was the best combiner for NMC and HR brix and these characters are important as selection criteria for cane yield and sugar yield, respectively. Among the testers, Co775 was found to be a good combiner for NMC and Co 89003 for HRbrix. These parents presumably possess relatively large number of favorable alleles for these characters and could be used in future programme for improving characters such as NMC, cane thickness and HR brix.

\section{Evaluation of crosses}

The specific combining ability effects of the inbred crosses are given in Table 4. Three crosses, viz., 83 R 23x Co 89003, 83 R 23x Co 775 , and Co $98014 x$ Co 89003 were the best specific combiners for NMC. Although 83 R 23 was a good general combiner for $\mathrm{NMC}$, all the crosses involving this line were not superior specific combiners for this trait indicating that a parent with good gca effect need not necessarily produce better cross combinations. A parent with poor gca, however, might also produce better hybrids (Tyagi and Lal 2005).In the present study, except 83 R 23 and ISH 100, all the lines and testers producing superior specific combiners are poor general combiners for NMC. For cane thickness too, the parents producing the best specific combiner (83 R 23x Co 775) were poor general combiners. The superiority of poor $\mathrm{x}$ poor general combiners to others might be due to over dominance and epistasis type of gene action influencing these traits. The crosses $83 \mathrm{R} 23 \mathrm{x}$ Co 1148, and Co 98013x Co 89003, which were good x good and poor $\mathrm{x}$ poor general combiners for $\mathrm{HR}$ brix, respectively were found to be the best specific combiners. These results indicated non-additive gene action for cane traits and both additive and non-additive gene action for HR brix.

Heterosis over better parent (heterobeltiosis) and mid-parent (relative heterosis) are given in Table 5. The relative heterosis for NMC varied from -20.34 (Co 98014x Co 775) to 88.12 (83 R 23x Co 775) and hetero beltiosis from -20.22 (Co 98014x Co 775) 74.13\% (83 $\mathrm{R} 23 \mathrm{x}$ Co 1148). The seven crosses involving 83 R 23x Co 775, 83 R 23x Co 1148, 83 R 23x Co 89003, ISH 100x Co 1148, ISH 100x Co 775, Co 98013x Co 1148 and Co C 671x Co 775 showed the highest desirable heterosis for NMC. The range of relative heterosis and hetero beltiosis for cane thickness were -9.20 to 9.12 and -10.10 to $4.29 \%$, respectively. The highest extreme was exhibited by the cross $83 \mathrm{R} 23 \mathrm{x}$ Co 775 while the lowest extreme was by Co $98013 x$ Co 1148 for both types of heterosis. Interestingly, the cross Co 98013x Co 1148 recording the lowest level heterosis in negative direction for NMC showed the highest level of heterosis in positive direction for cane thickness but the same relationship was not applicable to all the crosses. Heterosis for HR brix ranged from 8.40 to $18.46 \%$ (relative heterosis) and 9.42 to $9.23 \%$ (heterobeltiosis).

Among the 15 crosses, the three crosses Co 
7219x Co 775, Co C 671x Co 89003 and Co 98013 x Co 89003 recorded significant and desirable heterosis for HR brix. Similar variation in heterosis for yield related stalk traits has already been reported earlier (Aitken et al., 2008). Overall, the present study revealed that the inbreds $83 \mathrm{R} 23$ and a 'Co' clone Co 775 emerged as good general combiners for early stage selection traits in sugarcane. Crosses involving inbreds, viz. Three crosses, viz., 83 R 23x Co 89003, 83 R 23x Co 775, and Co 98014x Co 89003 were the best specific combiners for NMC, Co 7219x Co 775, Co C 671x Co 89003 and Co 98013x Co 89003 recorded significant and desirable heterosis for HR brix were identified as the best specific combiners. Both the categories of crosses, viz. good $\mathrm{x}$ good general combiners and poor $\mathrm{x}$ poor general combiners produced better specific combiners for the traits studied. The best general and specific combiners and the crosses with highheterotic effects identified in the study could beexploited in future breeding programmes.

\section{Acknowledgements}

The authors are thankful to the professor Jayashankar Telangana State Agricultural University, Rajendranagar, Hyderabad and the Sugarcane Breeding Institute, Coimbatore, for providing the logistic support for doing the crossing programme. The authors are also thankful to Mr. Arjun, Mr. Yakat and Mr. Akbar hussain for their support during the execution of the research work.

\section{References}

Aitken KS, Hermann S, Karno K, Bonnnet GD, McIntyre LC, Jackson PA (2008) Genetic control of yield related stalk traits in sugarcane. Theor Appl Genet 117:1191-1203.

Anna Durai, A. and Hema Prabha G. (2016).
Heterosis and combining ability of sugarcane inbreds for early stage selection traits. Journal of Sugarcane Research 6 (1): 27- 34.

Alarmelu S, Hemaprabha G, Nagarajan R, Shanthi RM (2010) Combining ability for yield and quality in sugarcane. Electronic J Plant Breed 1(4):742-746.

Anonymous (2016) Sugar Statistics. Coop Sug 47(12): 36-38.

Bakshi Ram, Hemaprabha G (2000) Combining ability and heterosis for cane yield and juice quality traits in progenies of sugarcane clones involving Saccharum robustum. Sugar Cane Int 2000 (2):10-15.

Bakshi Ram, Singh N, Sahi BK (2005) Combining ability and heterosis for disease index of red rot in sugarcane (Saccharum officinarum L.). Indian $\mathrm{J}$ Genet 65(2):112-114.

Bressiani JA, Burnquist WL, Fusatto SR, BonatoAL, Geraldi IO (2002) Combining abilityin eight selected clones of sugarcane (Saccharum sp). Crop Breed Appl Biotech2(3):411-416.

Cassalett C, Viveros CA, Pizza LR (1996) Self-pollination in sugarcane hybrids, Saccharum spp. ProcIntSoc Sugarcane Technol 22:312-315.

Chen RK, Xue QQ, Lin Q, Chen ZJ (1986) A study of the inheritance of quantitative characters in sugarcane. J Fujian AgricCollege 15(11):11-18.

Hogarth DM (1987) Genetic of sugarcane. In: Sugarcane Improvement through Breeding, (Heinz DJ, ed), II edn, pp. 255-272.Elsevier, Amsterdam.

Hongkai Z, Guifu L, Jiannong L, Juemin H (2009). Genetic analyses of sugarcane biomass yield and its component traits using ADAA model. J Trop Agric 47(123):70-73.

Killick RJ (1977) Genetic analyses of several traitsin potatoes by means of a diallel cross. AnnapplBiol 86:279-282. 
Lourdusamy A, Anbuselvam Y (2009) Combining ability in sugarcane. Madras agric J96.(1-6):55-61.

Punia MS (1986) Line x Tester analysis for combining ability in sugarcane. ProcIntSoc Sugarcane Technol 19:471477.

Rai JN, Singh HN, Saxena AK (1991) Combining ability in relation to heterosis for quantitative characters. Indian J Genet 51:96-101.

Singh RK, Chaudhary BD (1985) Biometrical
Methods in Quantitative Genetic Analysis. Kalyani Publishers, New Delhi.

Tyagi AP, Lal P (2005) Line x Tester analysis in sugarcane (Saccharum officinarum). S Pacif J Nat Sci 23:30-36.

Wu KK, Heinz DJ, Meyer HK, Ladds SL (1980)Combining ability and parental evaluation in five selected clones of sugarcane. Theor.Appl Genet 56:241244.

\section{How to cite this article:}

Bharathi, Y., Firdoz Shahana, T. Prabhakar Reddy and Vijaykumar, M. 2020. Combining Ability and Heterosis in Sugarcane for Early Selection Traits. Int.J.Curr.Microbiol.App.Sci. 9(07): 2473-2480. doi: https://doi.org/10.20546/ijcmas.2020.907.290 